\title{
スポーツサイクル・シティサイクル利用者の ルール認知および運転態度の比較分析
}

\author{
中嶋 悠人 1 -山中 英生 $2 \cdot$ 真田 純子 3 \\ 1学生会員 徳島大学 先端技術科学教育部（干770-8506 徳島県徳島市南常三島町2-1） \\ E-mail: maxyuuto@yahoo.co.jp \\ 2正会員 徳島大学教授 大学院ソシオテクノサイエンス研究部 \\ ( ₹770-8506 徳島県徳島市南常三島町2-1) \\ E-mail: yamanaka@ce.tokushima-u.ac.jp \\ 3 正会員 徳島大学助教 大学院ソシオテクノサイエンス研究部 \\ ( ₹770-8506 徳島県徳島市南常三島町2-1) \\ E-mail: sanajun@ce.tokushima-u.ac.jp
}

\begin{abstract}
クロスバイク，ロードバイク等のスポーツサイクル(以下 SC) は, 普及しているシティサイクル(以下 CC)に比べ, 高速・長距離・長時間の走行が可能であり, 全身運動にも優れているので, 中距離通勤や健 康活動に適しており, 環境や健康に資する自転車利活用する上でSCの活用が着目されている. また, 車道 で走行する SC利用者は，歩道走行が中心のCC利用者に比べて，安全走行の手本 (マナーリーダー)になり 得ることが期待される.

本研究では，SC利用者が， $\mathrm{CC}$ 利用者よりも本来の自転車ルール・マナーに対する認知及び走行態度の 安全性が高まっているかについて検証することを目的に, 両者の自転車ルール認知度, 運転態度を比較し た．その結果，SC利用者の中でもレベルが高いロングサイクリストがマナーリーダーになる可能性を有し ていることが明らかになった。
\end{abstract}

Key Words : sport bicycles, city bicycles, rule, driving attitude

\section{1. はじめに}

近年, 環境問題や健康意識の高まりから自転車が注目 されている. 日本では毎年販売される自転車の約 $60 \%$ を 低速・短距離・短時間の走行に適した CC が占めている が，最近はロードバイクやクロスバイクと呼ばれる SC の販売が増加している. SC は平成 15〜24 年度に販売台 数が約 3.4 倍になり, 全体の約 10\%を占めている ${ }^{1)}$.

健康促進, ダイエット効果がある適切な運動量は, 最 大心拍数の $60 \%$ 程度の心拍数で長時間(20 分以上)の運動 が必要とされるが 2)，SC は CC に比べて高速・長距離・ 長時間の走行が可能で，こうした健康に資する運動は CC より達成しや寸い，健康への配慮から通勤目的で自 動車から自転車に転換する際にも SC が多く選ばれてい る.

一方，平成 24 年 11 月に国土交通省，警察庁から発出 された安全で快適な自転車利用環境創出ガイドラインに おいては, 自転車乗車中の交通事故件数の増加を受けて, 車道部での左側通行を基本とした自転車通行空間整備を
中心に自転車ネットワークを整備する方針を示している. こうした車道部の自転車走行においても $\mathrm{SC}$ の利用が増 加することが予想される.

宇佐美ら 队2，歩道通行する自転車利用者とそうでな い利用者を比べると歩道通行する人の方が違反行動が多 く見られ, 歩道通行で自転車が優先されるという意識に 影響を受けているとしている.この結果からは，自らが 弱者となる車道で走行する $\mathrm{SC}$ 利用者は, 歩道通行中心 の $\mathrm{CC}$ 利用者に比べて, 安全走行の手本(マナーリーダ 一)になり得ることが期待される.

そこで，本研究では， $\mathrm{SC}$ 利用者が， $\mathrm{CC}$ 利用者よりも 本来の自転車のルールに対する認知が高まり, 利用時の 走行態度においても安全性が高まっているかについて意 識態度の調查によって検証することを目的とした.

具体的には，SC 利用者と $\mathrm{CC}$ 利用者を対象に自転車 ルール・マナーの認知度, 安全運転態度の WEB アンケ 一ト調査を行い，SC 利用者が CC 利用者に比べて優れ ている点を明らかにする。 


\section{2. 既存研究および本研究のアプローチ}

自転車利用のルールやマナーに対する認知の分析には 多様な研究が見られる，例えば，吉村ら ${ }^{4}$ は，高校生の 自転車利用の実態と自転車交通ルールの認識及び実際の 自転車走行時の行動を探り，これらに違いがあるか分析 している．また吉村・和田 ${ }^{5)}$ は，高校生を対象に交通ル 一ルの認識率と実際の行動での割合の差も分析している. さらに元田・宇佐美 ${ }^{\circ}$, 小中高生の自転車利用実態や 意識の違い, 事故に遭いやすい自転車乗車中の行動や意 識等を分析している.これより，自転車が走行すべき空 間を理解していないことや学年が上がるごとに交通ルー ルの遵守意識が減少すること等を明らかにしている。 ま た松村ら゙は，ヒヤリ地図を用いた自転車安全教育につ いて, 手法の検討を行い, 態度・交通行動変容を評価視 点に, その有効性を検証している.

このように，一般の自転車の交通ルールに関する研究 は行われているが，SCとCCに着目した研究は行われて いない.

そのため本研究では, SC利用者とCC 利用者の自転車 ルール・マナー及び運転態度を比較することで, 健康面, 環境面だけでなく, 交通安全面からもSC増進の重要性 を確認することを目的とした．この際，本研究では全国 の自転車利用者を対象に多様なルール・マナ一の知識, 運転態度について，利用者を区分して比較分析すること を重視して，意識調查手法を用いて分析を行うアプロー チをとることとした．これによって．SC，CCの利用意 識の相違を明らかにすることで，実態分析や教育方針へ と発展につながると考えたためである.

\section{SC 利用者及び CC 利用者への調査概要}

$\mathrm{SC}$ 利用者及び CC 利用者に対して WEB アンケート調 查を実施した。対象地域は全国とし，SC 利用者として ロードバイクやクロスバイク等の公道用 $\mathrm{SC}$ を月に 1 度 以上利用する人， $\mathrm{CC}$ 利用者として週 2 3 回以上， CC 等の一般の自転車を利用する人をスクリーニングで抽出 し，20 60 歳代の 10 歳レンジ 5 世代について男女別の 10 グループで均等に割付した. SC 利用者, CC 利用者と もに 500 サンプル（各グループ 500 サンプル）を回収し た. 調査は(株)楽天リサーチに委託した.

図-1，2，3 に SC 利用者の属性を示す. 経験年数が 1 $\sim 3$ 年未満の SC 利用者が多いことが確認できる. 利用 頻度は月に 1 2 回, 週に 1 2 回程度の SC 利用者が多 く, 週に 3 回以上利用する $\mathrm{SC}$ 利用者は少ない. 走行距 離 ${ }^{[1]}$ に関しては, $7 \mathrm{~km}$ 未満の $\mathrm{SC}$ 利用者の割合が最も高 く, 30km 以上走行する $\mathrm{SC}$ 利用者は少ないことがわかる. ここでは, SC 利用者を 1 日の走行距離に着目し, 利 用者のレベルによる分類を行った. 1 日の走行距離が
$7 \mathrm{~km}$ 未満(161 人)の $\mathrm{SC}$ 利用者をショートサイクリスト, 7〜 30km 未満(255 人)をミドルサイクリスト, $30 \mathrm{~km}$ 以上 (84人)の SC 利用者をロングサイクリストとする.

図-4，5 は CC のサンプル属性を示している. 利用頻 度は毎日から週 2 日ほどの 4 群がほぼ均等に分布してい る. 走行距離は 1 日 $1 \sim 4 \mathrm{~km}$ の利用者が多く, $1 \mathrm{~km}$ 末満 や $6 \mathrm{~km}$ 以下で $80 \%$ を占めており, 日本での一般的な自 転車利用状況にあっていることがわかる。

自転車ルール・マナーに関する認知を確認するため 30 項目の質問を構成した（後述表-1）。自転車の行動を 示し，「大切なルールである」，「重要なマナーであ る」，「マナーとしてすべきこと」，「正しいがしない 方がよい」，「マナーとして不適切」，「ルール違反で

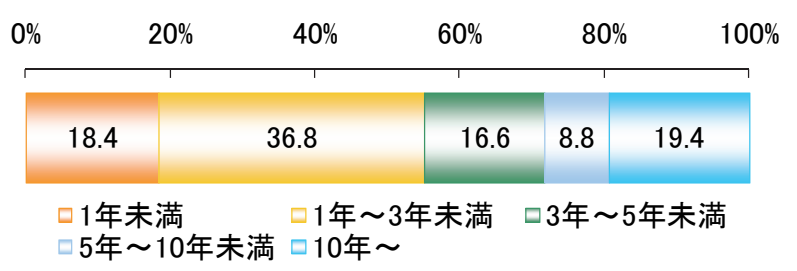

図-1 SC の経験年数

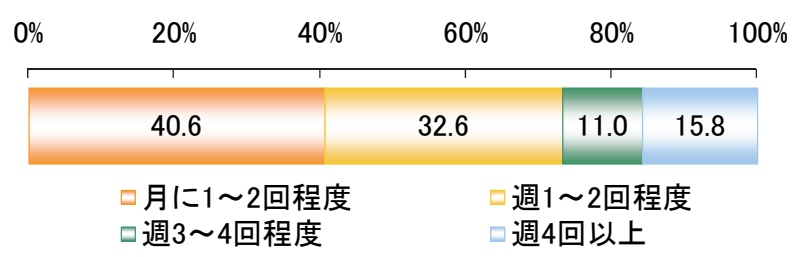

図-2 SC の利用頻度

a.

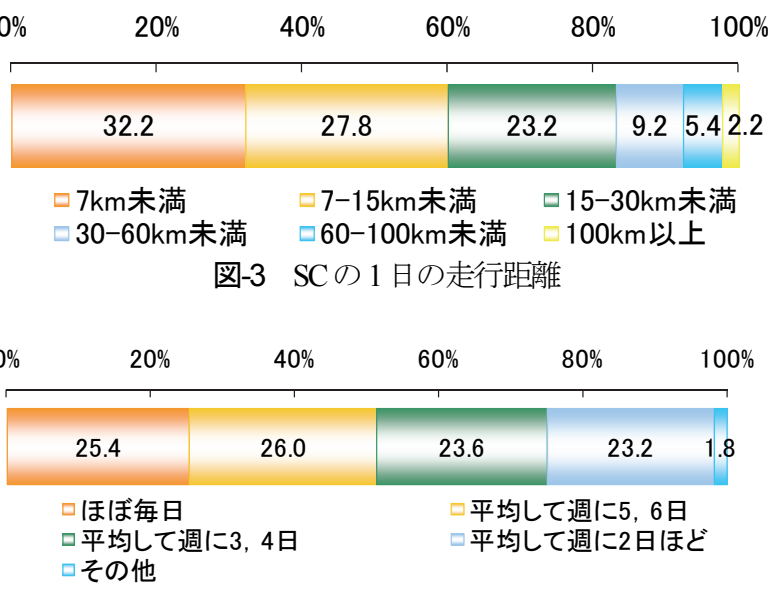

図-4 CC の利用頻度

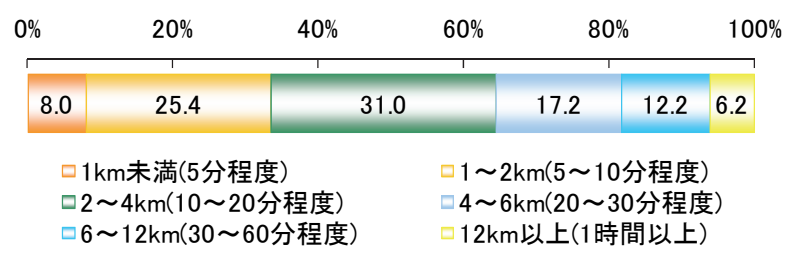

図-5 CC の 1 日の走行距離 
ある」の $6 つ の$ 選択肢を選ぶ質問となっている．運転態 度は 32 項目の質問から構成されている（後述表-6）。 普段の自転車走行時の運転場面を示して「はい」，「い いえ」の2 件法で回答を求めている.

\section{4. 自転車ルール・マナ一の分析方法及び結果}

\section{(1) 分析方法}

自転車ルール・マナーに関する 30 項目の質問を表-1 に示す．図-6 は質問で利用した図である，表に示すよ うに，質問項目は $\mathrm{R}($ 一般ルール) $\mathrm{M}$ (マナー)， $\mathrm{C}$ (車道 走行), $\mathrm{S}$ (歩道通行), I(交差点)の 5 区分に分類し, 質 問内容を省略して示寸キーワードを定めた，以下では， 分類記号とキーワードで略した質問項目で記述する，道 路交通法で定められているルールである行動(○), 道路 交通法で定められているルールに違反している $(\times)$, ル 一ルとして明確ではないが，自転車の使用上，重要性が 認識されている $(○)$, 法律で定められているが危険を伴 うためしない方がよい, マナーとして不適切であるもの $(\triangle)$ に区分して，回答がこの区分に適合している場合を

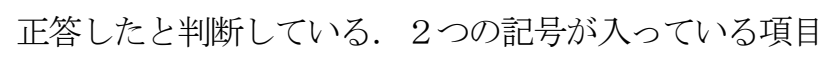
は文献等で意見が異なる場合があり，両者を正解とした ものである.

\section{(2) 分析結果}

\section{a) SC 利用者と CC 利用者の比較結果}

図-7 は, SC 利用者及び CC 利用者の自転車ルール・ マナーの正答率を示している. また，対応のない $\mathrm{t}$ 検定 を行い, 正答率の平均值に有意差( $\star 1 \%$ 未満, $\star \star 5 \%$ 未満 ※10\%未満)がみられたものを表記している.

これによると，SC 利用者は CC 利用者に比べて，青 信号確認, 犬連れ, 車道の左端, 第一通行帯, 一方通行, 子供高齢者歩道通行, 自転車横断帯, 二段階敷設, ハン ドサインの正答率が高く, 一部のマナ一や車道走行, 交 差点におけるルールの認知度が高い傾向にあることがわ かる，一方，CC利用者は SC 利用者に比べて，2 人乗り， 点検，TS マーク，ヘルメットの項目での正答率が高く, 一般ルールやマナーに関する認知度が SC 利用者よりも 高い傾向にある．逆に考えると，SC 利用者はこうした 一般的に教育されているルール・マナ一を軽視する傾向 があるとも考えられる.

以上のように，SC利用者とCC利用者の間には自転車 ルール・マナーの認知に違い見られる，そこで，一つの 質問項目の正解を 1 点とし，SC利用者及びCC利用者の自 転車ルール・マナーの正答数 (満点30)の平均值に差がみ られるか，対応のないt検定を用いて分析を行った.

表-2に，自転車ルール・マナーにおけるSC利用者及び $\mathrm{CC}$ 利用者の正答数の平均值を示寸. $\mathrm{SC}$ 利用者がCC利用
表-1 ルールマナーの認知に関する質問と正解

\begin{tabular}{|c|c|c|c|}
\hline No. & 質問項目 & 正解 & キーワード \\
\hline 1 & 携帯電話を使用しながら走行 & $\mathrm{x}$ & $\mathrm{R}$ 携帯 \\
\hline 2 & 大音量でイヤホンを使用し走行 & $x$ & Rイヤホン \\
\hline 3 & 夜間,ライトを点灯せずに走行 & $\bar{x}$ & $\mathrm{R}$ 無灯火 \\
\hline 4 & ビールを軽く飲み，自転車を運転した & $\bar{x}$ & $\mathrm{R}$ 飲酒 \\
\hline 5 & 自転車の2人乗り & $x$ & R 2人乗り \\
\hline 6 & 雨の日に傘を指して運転 & $\bar{x}$ & $\mathrm{R}$ 傘差L \\
\hline 7 & $\begin{array}{l}\text { 自転車乗車時, 毎回ライト・ブレーキ·タ } \\
\text { イヤを点検 }\end{array}$ & 0 & $M$ 点検 \\
\hline 8 & 交差点で青信号でも安全確認 & (0) & M 青信号確認 \\
\hline 9 & 自転車で犬を連れて走る & $x$ & M 犬連れ \\
\hline 10 & 「TSマーク」のある自転車を必ず使う & O & M TSマーク \\
\hline 11 & 歩道上に自転車を駐車した & $x$ & M 歩道駐輪 \\
\hline 12 & ヘルメット非着用で, 車道を走行 & $\triangle$ & $M$ ヘルルメット \\
\hline 13 & $\begin{array}{l}\text { 右折又は左折時に, 片手運転をして, } \\
\text { 曲り終わるまで手信号をだ続けるる }\end{array}$ & $\triangle$ & $\begin{array}{l}\text { M 片手ハンドサイ } \\
\text { ン }\end{array}$ \\
\hline 14 & $\begin{array}{l}\text { 駐車車両が間をあけてある時, 駐車車 } \\
\text { 両を避けたた後左側に寄り走行(図-6) }\end{array}$ & $\triangle$ & M ワインディング \\
\hline 15 & $\begin{array}{l}\text { 自転車で交差点の左折専用 } \\
\text { レーンを直進した }\end{array}$ & () & C 左端の車線 \\
\hline 16 & 自転車で車道の左端を走行 & (0) & C 車道の左端 \\
\hline 17 & $\begin{array}{l}\text { 片側2車線以上の道路で, 一番左側の } \\
\text { 車線の中央を走行 }\end{array}$ & () $\triangle$ & C 第一通行帯 \\
\hline 18 & $\begin{array}{l}\text { 一方通行(図-3)の標識のある道路で, } \\
\text { 自転車で逆走した }\end{array}$ & $x$ & C 一方通行 \\
\hline 19 & $\begin{array}{l}\text { 13歳未満の子供, 70歳以上の高齢者 } \\
\text { が自転車通行可でない歩道を通行 } \\
\end{array}$ & (0) & \begin{tabular}{|l|} 
S 子供高齢者歩 \\
道通行 \\
\end{tabular} \\
\hline 20 & $\begin{array}{l}\text { 自転車で通行中, 歩行者と衝突したが, } \\
\text { 謝って立ち去った }\end{array}$ & $x$ & S 歩行者と衝突 \\
\hline 21 & $\begin{array}{l}\text { 自転車通行可の標識(図-1)がある } \\
\text { 広い歩道で自転車で並んで通行 }\end{array}$ & $x$ & S 歩専併走 \\
\hline 22 & $\begin{array}{l}\text { 自転車通行可標識(図-1)がある歩道 } \\
\text { で, 歩行者が范ないのでル゙を鳴らした }\end{array}$ & $x$ & S 歩専ベル \\
\hline 23 & $\begin{array}{l}\text { 図-5の標識のある道路で, 歩行者に } \\
\text { 気をつけながら自転車で通行 }\end{array}$ & () & $S$ 自歩道徐行 \\
\hline 24 & $\begin{array}{l}\text { 自転車横断通行帯のある交差点では, } \\
\text { 必ず車道から通行帯を通って渡る }\end{array}$ & $\triangle$ & \begin{tabular}{|l} 
I 自転車横断通 \\
行带
\end{tabular} \\
\hline 25 & $\begin{array}{l}\text { 止まれの標識(図-2)のある交差点で, } \\
\text { 自転車で徐行して通行した }\end{array}$ & $x$ & I 止まれ標識 \\
\hline 26 & $\begin{array}{l}\text { 信号交差点で自動車と同様に右折した } \\
\text { (図-4) }\end{array}$ & $x$ & I 信号右折 \\
\hline 27 & $\begin{array}{l}\text { 車道走行中, 歩行者·自転車用信号を } \\
\text { みて交差点に進入 }\end{array}$ & $\triangle$ & I 自転車用信号 \\
\hline 28 & $\begin{array}{l}\text { 無信号交差点で, 二段階右折を } \\
\text { せずに右折した }\end{array}$ & $x$ & I 二段階右折 \\
\hline 29 & $\begin{array}{l}\text { 右折·左折をする時に, 手を使って } \\
\text { 信号をする }\end{array}$ & () & I ハンドサイン \\
\hline 30 & $\begin{array}{l}\text { 交差点で, 自動車に見えるよう, } \\
\text { 自動車の停止線を超えて停止 }\end{array}$ & $\times, O$ & I 停止線越停止 \\
\hline
\end{tabular}

注釈）14:こうした走行の危険性は米国の安全ガイド(たとえばSafe Bicycling in San Francisco (wordspace press 2001)に記載されている.17ルール上問題ない. ただし危険を 伴う場合も生じうるため $\Delta も$ 正解とした. 18 : 軽車両除外の表示について記載がないため×で ある. 30 : 我が国では違反であるが, 自動車の前で停止する方策が推将されているため○も 正解とした.

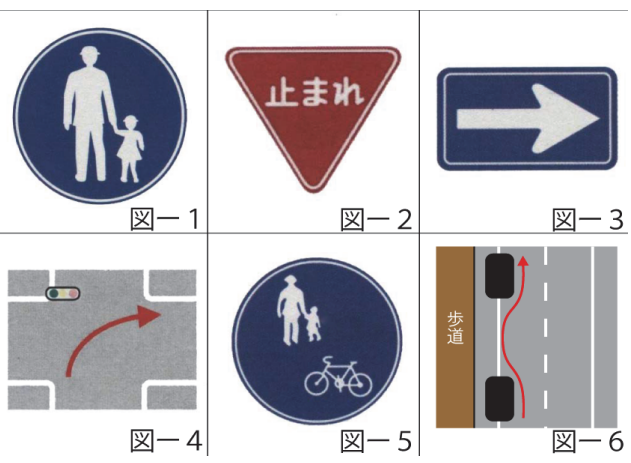

図-6 ルールマナ一認知の質問で利用した図

(表-1では図-1を自転車通行可の標識と意図的に誤って説明している) 


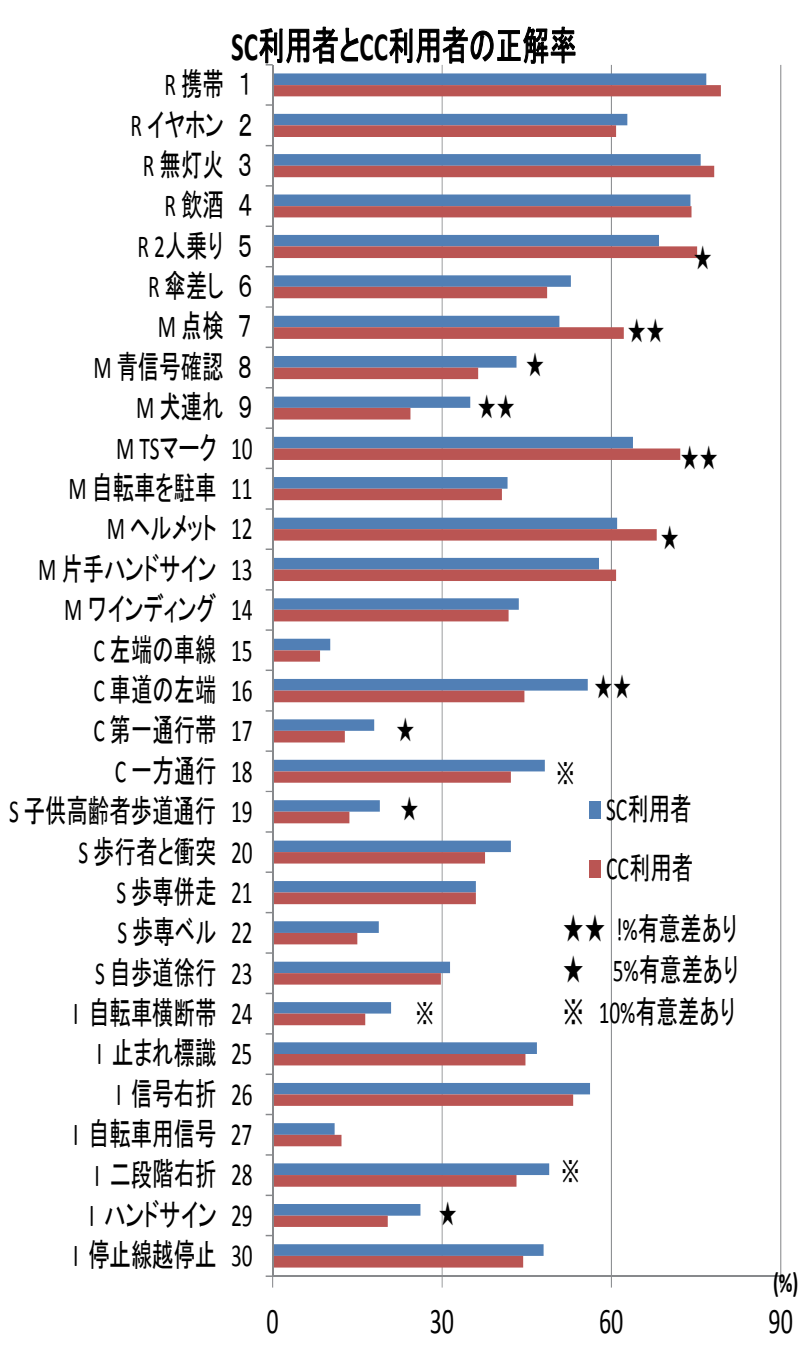

図-7 SC/CC 利用者のルールマナーの正答率

者よりも高い正答の傾向が見られるが，平均值の差につ いてはp值が0.114と，5\%水準では必ずしも有意とはいえ ない結果となった.

\section{b) 分類項目別の比較}

表-3は，自転車ルール・マナーの分類項目ごとのSC利 用者とCC利用者の正答の平均値を示している. 分類項 目ごとの平均正答率は，一般ルール6点，マナー8点，車 道走行 4 点, 歩道通行 5 点, 交差点7点で除して, 正答率 を示している. SC利用者とCC利用者の正答率について 対応のない検定を用いて平均值の差に有意差 $(\star \star 1 \%$ 水 準， で数值が示されている項目はSC利用者がCC利用者より も正答率が高いことを示している. 有意差に着目寸ると, $\mathrm{CC}$ 利用者よりも $\mathrm{SC}$ 利用者の平均值が高いことを示して いる. 寸なわち，一般ルール，マナーのような常識的な 知識に関しては, SC利用者とCC利用者に認知の違いは みられないが，車道や歩道，交差点での走行に関する知 識やマナーに関しては，SC利用者の方が，認知度が高 い傾向にあることがわかほる.
表-2 自転車ルール・マナーの正答数の平均値の差

\begin{tabular}{|l|c|}
\hline & 総得点平均値 \\
\hline $\mathrm{SC}$ 利用者 & 13.452 \\
\hline $\mathrm{CC}$ 利用者 & 12.974 \\
\hline $\mathrm{t}$ 值 & 1.58 \\
\hline $\mathrm{p}$ 値 & 0.114 \\
\hline
\end{tabular}

表-3 分類項目別自転車ルール・マナ一認知度の比較

\begin{tabular}{|c|c|c|c|c|c|}
\hline & 一般ルール & マナー & 車道走行 & 歩道通行 & 交差点 \\
\hline SC利用者 & 0.694 & 0.508 & 0.270 & 0.264 & 0.335 \\
\hline CC利用者 & 0.684 & 0.496 & 0.331 & $\mathbf{0 . 2 9 5}$ & $\mathbf{0 . 3 6 9}$ \\
\hline 差 & -0.010 & -0.012 & 0.061 & $\mathbf{0 . 0 3 1}$ & $\mathbf{0 . 0 3 4}$ \\
\hline t値 & -0.470 & -1.003 & 4.247 & $\mathbf{2 . 0 1 9}$ & $\mathbf{2 . 5 1 1}$ \\
\hline p 值 & 0.638 & 0.316 & $\mathbf{0 . 0 0 0}$ & $\mathbf{0 . 0 4 4}$ & $\mathbf{0 . 0 1 2}$ \\
\hline 有意差 & & & $\star \star$ & $\star$ & $\star$ \\
\hline
\end{tabular}

表-4 自転車ルール・マナ一認知度の比較 (レベル別)

\begin{tabular}{|c|c|c|c|c|c|}
\hline & 一般ルール & マナー & 車道走行 & 歩道通行 & 交差点 \\
\hline $\mathrm{CC}$ & 0.694 & 0.508 & 0.270 & 0.264 & 0.335 \\
\hline SCショート & 0.660 & 0.488 & 0.303 & 0.275 & 0.372 \\
\hline 差 & -0.034 & -0.020 & 0.033 & 0.011 & 0.037 \\
\hline t值 & -1.187 & -1.220 & 1.618 & 0.488 & 1.907 \\
\hline p值 & 0.236 & 0.223 & 0.106 & 0.626 & 0.057 \\
\hline 有意差 & & & & & $※$ \\
\hline SCミドル & 0.683 & 0.506 & 0.343 & 0.297 & 0.364 \\
\hline 差 & -0.011 & -0.002 & 0.073 & 0.033 & 0.028 \\
\hline t値 & -0.446 & -0.148 & 4.195 & 1.796 & 1.729 \\
\hline p值 & 0.656 & 0.882 & 0.000 & 0.073 & 0.084 \\
\hline 有意差 & & & $\star \star$ & $※$ & $※$ \\
\hline SCロング & 0.734 & 0.482 & 0.345 & 0.326 & 0.379 \\
\hline 差 & 0.040 & -0.026 & 0.075 & 0.062 & 0.044 \\
\hline t値 & 1.080 & -1.184 & 2.863 & 2.179 & 1.728 \\
\hline p值 & 0.281 & 0.237 & 0.004 & 0.030 & 0.084 \\
\hline 有意差 & & & $\star \star$ & $\star$ & $※$ \\
\hline
\end{tabular}

また，表-4は自転車ルール・マナーの分類項目ごとの 正答率について，SC利用者を3つのレベルに区分してCC 利用者との平均正答率の差を示している. 同様にSC利 用者の各レベルとCC利用者の正答率について対応のな い検定を用いて平均值に有意差があるかを推定してい る. 同じく太字で数值が示されている項目はSC利用者 がCC利用者よりも正答率が高いことを示している.

$\mathrm{SC}$ 利用者のレベルが高くなるほど，車道走行，歩道 通行, 交差点のルール・マナ一の認知度が高くなる傾向 が見られ，CC利用者とも有意差が生じている．特に車 道走行に関してミドル，ロングのSC利用者の認知度は CC利用者との有意差が明らかである。こうしたレベル の高いSC利用者は, 車道部を走行する際の安全性を確 保するため，走行位置や走行マナーを意識していること が示唆される. 
表-5 ルール・マナ一項目別認知度の比較 (SCレベル別)

\begin{tabular}{|c|c|c|c|}
\hline ルール/マナーの認知 & $\begin{array}{l}\mathrm{SC} \\
\text { ショート }\end{array}$ & $\begin{array}{l}\text { SC } \\
\text { ミドル }\end{array}$ & $\begin{array}{l}\mathrm{SC} \\
\text { ロング }\end{array}$ \\
\hline \multicolumn{4}{|l|}{$\mathrm{R}$ 携帯 1} \\
\hline \multicolumn{4}{|l|}{ R イヤホン 2} \\
\hline $\mathrm{R}$ 無灯火 3 & ※ & & \\
\hline \multicolumn{4}{|l|}{$\mathrm{R}$ 飲酒 4} \\
\hline R 2人乗り 5 & ※ & $\star$ & \\
\hline $\mathrm{R}$ 傘差し 6 & & & $\star \star$ \\
\hline $\mathrm{M}$ 点検 7 & ※ & 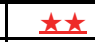 & $\underline{t}$ \\
\hline$M$ 青信号確認 8 & & $\star$ & \\
\hline$M$ 犬連れ 9 & $\star$ & $\star$ & $\star \star \star$ \\
\hline M TSマーク 10 & 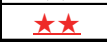 & & \\
\hline \multicolumn{4}{|l|}{ M 自転車を駐車 11} \\
\hline $\mathrm{M}$ ヘルメット 12 & & ※ & 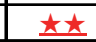 \\
\hline \multicolumn{4}{|l|}{ M 片手ハンドサイン 13 } \\
\hline \multicolumn{4}{|l|}{ M ワインディング 14} \\
\hline \multicolumn{4}{|l|}{ C 左端の車線 15} \\
\hline $\mathrm{C}$ 車道の左端 16 & & $\star \star \star$ & $\star \star$ \\
\hline C 第一通行帯 17 & $※$ & $\star$ & \\
\hline $\mathrm{C}$-方通行 18 & & $\star$ & \\
\hline S 子供高齢者歩道通行 19 & ※ & & ※ \\
\hline S 歩行者と衝突 20 & & $※$ & \\
\hline \multicolumn{4}{|l|}{$S$ 歩専併走 21} \\
\hline$S$ 歩専ベル 22 & & $※$ & $\star$ \\
\hline \multicolumn{4}{|l|}{$S$ 自歩道徐行 23} \\
\hline I 自転車横断帯 24 & & & $※$ \\
\hline I 止まれ標識 25 & & & ※ \\
\hline \multicolumn{4}{|l|}{ I 信号右折 26} \\
\hline \multicolumn{4}{|l|}{ I 自転車用信号 27} \\
\hline I 二段階右折 28 & $\star$ & & \\
\hline I ハンドサイン 29 & & $\star$ & \\
\hline I 停止線越停止 30 & & & \\
\hline
\end{tabular}

$\star \star 1 \%$ 有意 $\star 5 \%$ 有意 $※ 10 \%$ 有意 空欄有意差なし 赤字下線はSCがCCより劣る

\section{c) 項目別SCレベル別の比較}

さらに，表-5は30項目それぞれについてSC利用者の 各レベル別に， $\mathrm{CC}$ 利用者との正解率の有意差を整理し たものである．有意差( $\star \star 1 \%$ 未満， $\star 5 \%$ 未満， $※ 10 \%$ 未満)が見られたものを表記している. 項目別にみると 有意な差が現れる項目は多くはない.

特にSC利用者の正解率がCC利用者より低かった項目 に着目すると（赤字下線付で示している），このような 項目は一般ルール，マナーの一部に見られるだけで車道 走行, 歩道走行, 交差点の項目には見られない. しかも ロングのSC利用者では，点検，ヘルメットの項目のみ と少なくなっている.

\section{5. 運転態度の分析方法及び結果}

\section{(1) 質問項目の作成方法}

運転態度に関する質問項目は科学警察研究所で開発さ れた安全運転態度検査SAS592 ${ }^{8)}$ を参考に作成した。

SAS592は大塚博保らが，運転免許更新の機会を利用し て安全運転の動機付けをするため，運転者の安全運転意 表-6＼cjkstart運転態度における質問及び分類項目

\begin{tabular}{|c|c|c|}
\hline & & 質問項目 \\
\hline & 1 & 青信号に変わりそうだと, 動き出す \\
\hline 危 & 2 & 合図をせずに停止, 急な右左折をする \\
\hline 険 & 3 & 音楽を聴きながら自転車に乗りたい \\
\hline 性 & 4 & 信号が赤でも車が来ていなければ渡る \\
\hline の & 5 & 友達とよく並走する \\
\hline 高 & 6 & 狭い交差点を曲がる時周りを確認しない \\
\hline い & 7 & 片手·手放し運転をしてしまう \\
\hline 違 & 8 & つい気軽に道路を変えてしまう \\
\hline 反 & 9 & 携帯電話を見ながら運転できる \\
\hline & 10 & 一時停止の場所で止まらない \\
\hline 高 & 11 & 前があいていると, スピードを出す \\
\hline 速 & 12 & ふと気づくとスピードが出ている \\
\hline 度 & 13 & カーブでもスピードを落とさず走れる \\
\hline 運 & 14 & 狭い道でも思いのまま走れる \\
\hline 転 & 15 & 角を曲がると，急な加速をする \\
\hline & 16 & よく追い越しをするほうだ \\
\hline 他 & 17 & 歩行者や自転車が多くてもうまく交せる \\
\hline 考 & 18 & 停止している車のそばを気にせず通る \\
\hline 百 & 19 & 歩行者のそばを早く走り抜けるほうだ \\
\hline$\widehat{\infty}$ & 20 & ベルをよく鳴らす \\
\hline 举 & 21 & 歩行者や自転車が来ても端に寄らない \\
\hline & 22 & 狭い道でのすれ違いでも, 先に行く \\
\hline 野 & 23 & もたもた歩いている歩行者は無視をする \\
\hline & 24 & 自転車が来ても，躊躇なく右左折できる \\
\hline & 25 & 進路を妨害されたときは, 腹が立つ \\
\hline 他 & 26 & 他の自転車に腹を立てることが多い \\
\hline 者 & 27 & ルール無視の歩行者には接触しても仕方ない \\
\hline$へ$ & 28 & 歩行者を邪魔だと感じることがある \\
\hline の & 29 & 人から運転が危ないと言われた \\
\hline 感 & 30 & 遅い歩行者はイライラする \\
\hline 情 & 31 & 近くに自転車が走っていると邪魔だ \\
\hline & 32 & 停止するのがきらい \\
\hline
\end{tabular}

識，態度の程度を測定，評価する指標として開発したも のである. 検査は他者迷惑行動要素としての感情高揚性, 自己顕示性，他者排除行動要素の攻撃性，非協調行動要 素の4区分計32の質問から構成されている.

本研究では，この質問項目を自転車利用時の行動とし て置き換えて質問を作成した．表-5に作成した質問項目 及び分類項目を示す.

危険性の高いと考えられる行動が示されていることか ら，質問に対して「はい」と答えた場合が多いほど安全 運転態度が低いことを示す。

自転車に関して作成した質問への回答では，SAS592 の元の4区分では，SCとCCに有意差が明確でなかった. このため，新たに表中に示す「危険性の高い違反」， 「高速度運転」，「他者への挙動」，「他者への感情」 の4分類に区分し直して集計することとした.

(2) 分析結果

a) 質問項目全体の比較

図-8は各質問について「はい」とした（危険な態度・ 行動をとるとした）回答者の割合をSC利用者とCC利用 者で比較した結果を示している。また，対応のない検 定を行い，回答者割合の平均值に有意差( $\star \star 1 \%$ 未満, 


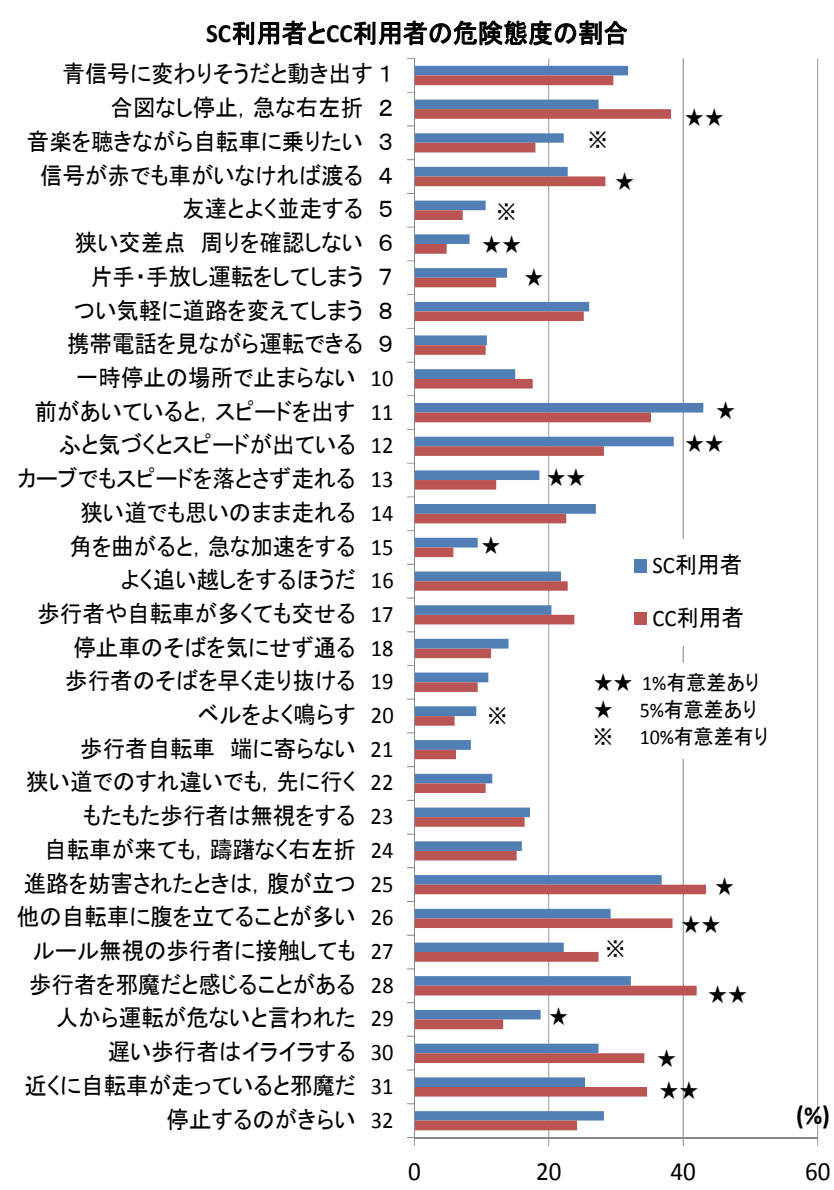

図-8 SC利用者とCC利用者の危険態度の割合

Ł $5 \%$ 未満，※10\%未満)が見られたものを表記している SC利用者は，「前があいていると，スピードを出 す」，「ふと気づくとスピードが出ている」「カーブで も速度を落とさず曲がれる」「角を曲がると急加速す る」等の割合がCC利用者よりも高く，高速での運転を する傾向が見られる．ただし，車道走行時はある程度の 速度維持が必要なことも考えられるため, これらの態度 は必ずしも危険運転とは言えない可能性もある.「ベル を鳴らす」もCC利用者よりも高くなっているが，同様 の可能性が考えられる。これ以外に「音楽を聴きなが ら」「併走」「狭い交差点での不注意」「片手手放し運 転」「運転が危ないといわれる」といった項目でCC利 用者よりも高い率が見られる。これらには，運転能力八 の過剒な自信が推察される.

一方， $\mathrm{CC}$ 利用者は，「他の自転車に腹を立てること が多い」，「歩行者を邪魔だと感ることがある」等の割 合がSC利用者より高く，他者に対する不満を持つ傾向 が高いことがわかる.

\section{b) 質問項目を集計した態度の比較}

各質問項目に「はい」とした回答を1点として全質問 での正答についてSC利用者及びCC利用者の平均值を算 定した．さらに，SC，CC利用者の差を対応のない検定 を用いて分析を行った. 表-7にその結果を示す.このよ うにSC利用者とCC利用者の間で運転態度の全項目での
表-7 SC, CC 利用者の運転態度の平均值と差検定

\begin{tabular}{|l|l|}
\hline & 総得点平均値 \\
\hline SC利用者 & 6.75 \\
\hline $\mathrm{CC}$ 利用者 & 6.75 \\
\hline $\mathrm{t}$ 値 & 0 \\
\hline $\mathrm{p}$ 値 & 1.000 \\
\hline
\end{tabular}

表-8 分類項目別運転態度の比較

\begin{tabular}{|c|c|c|c|c|}
\hline & $\begin{array}{c}\text { 危険性の } \\
\text { 高い違反 }\end{array}$ & $\begin{array}{c}\text { 高速度 } \\
\text { 運転 }\end{array}$ & $\begin{array}{c}\text { 他者への } \\
\text { 挙動 }\end{array}$ & $\begin{array}{c}\text { 他者への } \\
\text { 感情 }\end{array}$ \\
\hline SC利用者 & 0.189 & 0.274 & 0.144 & 0.275 \\
\hline CC利用者 & 0.192 & 0.208 & 0.135 & 0.322 \\
\hline 差 & -0.003 & 0.066 & 0.009 & -0.047 \\
\hline t値 & -0.229 & 3.762 & 0.631 & -2.549 \\
\hline p値 & 0.819 & 0.000 & 0.528 & 0.011 \\
\hline 有意差 & & $\star \star$ & & $\star$ \\
\hline
\end{tabular}

平均值を比較した結果, 両者に差はみられなかった。

\section{c) 分類項目ごとの態度の比較}

表-8は，危険態度の分類項目ごとに，SC利用者とCC 利用者の運転態度の平均值を比較した結果を示している. 分類項目ごとの平均正答率は, 危険性の高い違反 10 点, 高速度運転5点，他者への挙動9点，他者への感情8点で 除して正答率を示している. 検定を用いて，平均値の 差に有意差があるか検定した, 表中の有意差の項目は, $\mathrm{CC}$ 利用者よりも SC利用者の平均值が有意 $(\star \star 1 \%$ 水準, $\star 5 \%$ 水準，※10\%水準)に高いと判断できる場合を示し ている. 数值を太字で示している項目は, SC利用者が CC利用者よりも平均值が低い（安全側）であることを 示している.

危険性の高い違反や他者に対する危険な態度について は，SC利用者とCC利用者の間に違いはみられなかった。 一方で，前述したとおり，高速度運転に関しては，SC 利用者の方がCC利用者より高い傾向があり，CC利用者 に比べてSC利用者の方がスピードを出しやすい態度に なっている，しかし，他者への感情に関しては，CC利 用者の方が有意に高く, 危険な傾向が見られる.

また，表-9は， SC利用者の各レベルとCC利用者につ いて，危険態度の分類項目ごとの差を示したものである. ショートのSC利用者については，CC利用者との間で， 運転態度に有意な違いは見られないが，ミドル・ロング のSC利用者は，前述したとおりCC利用者より高速の運 転をする傾向は顕著である.

他者への感情の項目に着目すると，ミドル，ロングの $\mathrm{SC}$ 利用者はCC利用者より有意に低くなっており, ショ 一トのSC利用者を除いて，SC利用者はCC利用者よりも， 他者に対して不満を持たない傾向にあるといえる.これ は，車道走行をする高いレベルのSC利用者に比べると， $\mathrm{CC}$ 利用者は日常で歩道走行中に歩行者等の他者との関 わりを持ち，しかも邪魔な感情を有するといった強者と しての側面をもつことを示唆していると考えられる. 
表-9 運転態度の比較 (レベル別)

\begin{tabular}{|c|c|c|c|c|}
\hline & $\begin{array}{c}\text { 危険性の } \\
\text { 高い違反 }\end{array}$ & $\begin{array}{c}\text { 高速度 } \\
\text { 運転 }\end{array}$ & $\begin{array}{c}\text { 他者への } \\
\text { 挙動 }\end{array}$ & $\begin{array}{c}\text { 他者への } \\
\text { 感情 }\end{array}$ \\
\hline $\mathrm{CC}$ & 0.192 & 0.208 & 0.135 & 0.322 \\
\hline $\mathrm{SCショート}$ & 0.185 & 0.234 & 0.132 & 0.299 \\
\hline 差 & -0.007 & 0.026 & -0.004 & -0.023 \\
\hline $\mathrm{t}$ 值 & -0.353 & 1.104 & -0.192 & -0.870 \\
\hline $\mathrm{p}$ 值 & 0.724 & 0.270 & 0.848 & 0.385 \\
\hline 有意差 & & & & \\
\hline $\mathrm{SCミドル}$ & 0.196 & 0.298 & 0.156 & 0.276 \\
\hline 差 & 0.004 & 0.090 & 0.021 & -0.046 \\
\hline $\mathrm{t}$ 値 & 0.232 & 4.298 & 1.164 & -2.053 \\
\hline $\mathrm{p}$ 值 & 0.816 & 0.000 & 0.245 & 0.040 \\
\hline 有意差 & & $\star \star$ & & $\star$ \\
\hline SCロング & 0.174 & 0.274 & 0.130 & 0.228 \\
\hline 差 & -0.018 & 0.066 & -0.006 & -0.094 \\
\hline $\mathrm{t}$ 值 & -0.733 & 2.141 & -0.236 & -2.831 \\
\hline $\mathrm{p}$ 值 & 0.464 & 0.033 & 0.814 & 0.005 \\
\hline 有意差 & & $\star \star \star$ & & $\star \star$ \\
\hline
\end{tabular}

表-10 項目別運転態度の比較（レベル別）

\begin{tabular}{|c|c|c|c|c|c|}
\hline \multicolumn{3}{|r|}{ 質問項目 } & $\begin{array}{l}\mathrm{SC} \\
\text { ショート }\end{array}$ & $\begin{array}{l}\text { SC } \\
\text { ミドル }\end{array}$ & $\begin{array}{l}\mathrm{SC} \\
\text { ロング }\end{array}$ \\
\hline \multirow{10}{*}{$\begin{array}{l}\text { 危 } \\
\text { 険 } \\
\text { 性 } \\
\text { の } \\
\text { 高 } \\
\text { い } \\
\text { 違 } \\
\text { 反 }\end{array}$} & 1 & 青信号に変わりそうだと, 動き出す & & & \\
\hline & 2 & 合図をせずに停止, 急な右左折をする & $\star$ & $\star \star \star$ & $\star$ \\
\hline & 3 & 音楽を聴きながら自転車に乗りたい & ※ & & \\
\hline & 4 & 信号が赤でも車が来ていなければ渡る & & & $\star$ \\
\hline & 5 & 友達とよく並走する & & ※ & $\underline{\underline{t}}$ \\
\hline & 6 & 狭い交差点を曲がる時周りを確認しない & & 太 & \\
\hline & 7 & 片手·手放し運転をしてしまう & & & \\
\hline & 8 & つい気軽に道路を変えてしまう & & & \\
\hline & 9 & 携帯電話を見ながら運転できる & & & \\
\hline & 10 & 一時停止の場所で止まらない & & & \\
\hline \multirow{5}{*}{$\begin{array}{l}\text { 高 } \\
\text { 速 } \\
\text { 度 } \\
\text { 運 } \\
\text { 転 }\end{array}$} & 11 & 前があいていると, スピードを出す & & 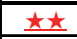 & \\
\hline & 12 & ふと気づくとスピードが出ている & & 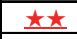 & 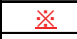 \\
\hline & 13 & カーブでもスピードを落とさず走れる & & $\star$ & 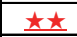 \\
\hline & 14 & 狭い道でも思いのまま走れる & & $\underline{\underline{t}}$ & \\
\hline & 15 & 角を曲がると，急な加速をする & & 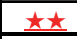 & \\
\hline \multirow{9}{*}{$\begin{array}{l}\text { 他 } \\
\text { 者 } \\
\widehat{0} \\
\text { の } \\
\text { 挙 } \\
\text { 動 }\end{array}$} & 16 & よく追い越しをするほうだ & $※$ & & \\
\hline & 17 & 歩行者や自転車が多くてもうまく交せる & & & $※$ \\
\hline & 18 & 停止している車のそばを気にせず通る & & & \\
\hline & 19 & 歩行者のそばを早く走り抜けるほうだ & & & \\
\hline & 20 & ベルをよく鳴らす & & $\star$ & \\
\hline & 21 & 歩行者や自転車が来ても端に寄らない & & & \\
\hline & 22 & 狭い道でのすれ違いでも, 先に行く & & & \\
\hline & 23 & もたもた歩いている歩行者は無視をする & & & \\
\hline & 24 & 自転車が来ても，躊躇なく右左折できる & & & \\
\hline \multirow{8}{*}{$\begin{array}{l}\text { 他 } \\
\text { 者 } \\
\text { へ } \\
\text { の } \\
\text { 感 } \\
\text { 情 }\end{array}$} & 25 & 進路を妨害されたときは, 腹が立つ & & & $\star$ \\
\hline & 26 & 他の自転車に腹を立てることが多い & $\star$ & $\star$ & $※$ \\
\hline & 27 & $\begin{array}{l}\text { ルール無視の歩行者には接触しても仕方ない } \\
\end{array}$ & & $\star$ & \\
\hline & 28 & 歩行者を邪魔だと感じることがある & & $\star$ & $\star \star \star$ \\
\hline & 29 & 人から運転が危ないと言われた & & $\underline{\underline{t}}$ & \\
\hline & 30 & 遅い歩行者はイライラする & & $\star$ & $\star \star$ \\
\hline & 31 & 近くに自転車が走っていると邪魔だ & & $\star \star$ & $\star \star$ \\
\hline & 32 & 停止するのがきらい & & & \\
\hline
\end{tabular}
赤字下線はSCがCCより危険態度が高い

\section{d) 項目別SCレベル別の態度の比較}

さらに，表-10は32項目それぞれについてSC利用者の 各レベル別にCC利用者との差を整理したものである.

有意差 $(\star \star 1 \%$ 未満， $\star 5 \%$ 未満，※10\%未満)が見られ たものを表記している.SCショートは有意差が見られ る項目は少ないが, 合図, 追い越し, 他の自転車でCC 利用者より改善しており, 唯一音楽でCC利用者より悪 い.

ミドルとロングのSC利用者で，CC利用者より高い危 険態度を示した項目に着目寸ると, 高速度運転がミドル
に顕著に見られるが，ロングでは高速度運転は2項目に 減っている，また，ミドルでは，併走，狭い交差点，心゙ ル，危険運転の指摘経験などでCC利用者よりも問題が あることが見られるが，ロングでは併走だけが有意に問 題となっている.

\section{6. おわりに}

$\mathrm{SC}$ 利用者の 1 日の利用距離 $7 \mathrm{~km}$ 未満のショートサイク リストとCC利用者の間では自転車ルール・マナー及び 運転態度に違いはみられなかった。

$\mathrm{SC}$ 利用者でも1日の利用距離が7〜 30kmのミドルサイ クリストとCC利用者の間では, SC利用者が車道走行に おける自転車ルール・マナーの認知度が高い傾向にあり， 車道での正しい走行ができる可能性がある．運転態度に 関しては，他者への不満は持たない傾向にあるが，高速 運転などの傾向が見られる.

$\mathrm{SC}$ 利用者の利用距離 $30 \mathrm{~km}$ 以上のロングサイクリスト とCC利用者の間では，SC利用者が車道走行及び歩道通 行における自転車ルール・マナーの認知度が高い傾向に あり，車道での正しい走行や歩道通行時のマナーを守れ る可能性がある. 運転態度に関しても，他者への不満を 持たない傾向にある. SC利用者の中でも，ロングサイ クリストはマナーリーダーになる可能性を有していると いえる.

ただし，他者への挙動の運転態度では，SC利用者は $\mathrm{CC}$ 利用者と比べて必ずしも優れているとは言えず，口 ングサイクリストでもこの傾向に変化が見られない.ま た，ロングサイクリストは点検，ヘルメットといった一 般的に教育されているルールへの軽視が見られ，さらに は，運転態度で「併走」など必ずしもマナーリーダーと は言えない点も見られることに留意すべきと言える.

今後は, SC/CC利用者の自転車ルール・マナーや運転 態度の実態を把握して分析を増強することが考えられる. ただし，本研究で明らかになったようにSC利用者のレ ベルを把握することが重要であることから，公道での観 測ではなく, モニターによるテスト走行分析などの手法 を用いることが必要と考えられる.

さらには，SC利用者の増進が見られる中で，ショー トのSC利用者がミドル，ロングのSC利用者に比べてマ ナー・ルール，運転態度が劣ることは，これらのユーザ 一に対する適切な教育の必要性を示唆している. このた めにも，ショートサイクリストが自転車愛好を高めてミ ドル，ロングサイクリストになることで，正しい自転車 ルール・マナーや運転態度を身に付けるのかを検証する 必要があると考えられる. 


\section{補注}

[1]ここでの走行距離の質問は「スポーツサイクルを利 用するときの1日の走行距離はどの程度ですか?」とし ており，1日のサイクリングで走るおおよそ距離を解答 させている．年間走行距離を1日あたりに平均した值で はない.

\section{参考文献}

1) 自転車産業振興協会：国内販売動向調査 平成 15 年 24 年度

2) 絹代：自転車でカラダとココロのシェイプアップ, pp.74-75, 140-141， 2008.

3) 宇佐美誠史，元田良孝，後藤俊，高橋慶多：自転車の歩 道通行と交通違反の関連に関する研究，土木計画学研 究・講演集, Vol.47, CD-ROM, 2013.
4) 吉村朋矩, 三寺潤, 和田章仁 : 高校生を対象と自転 車走行に関する交通ルールの認識と尊守実態，福井 工業大学研究紀要, pp.251-258, 2012.

5) 吉村朋矩, 和田章仁：高校生を対象とした自転車通 行に関する交通ルールの認識とその行動実態，土木 計画学研究・講演集, Vol.44, 2011.

6) 元田良孝，宇佐美誠史：小中高生の自転車の安全利 用に対する意識と行動，事故の危険性，交通工学研 究発表会論文集, Vol.29, pp.53-56, 2009.

7) 松村暢彦，伊藤大介，新田保次：「自転車ヒヤリ地 図」による態度・交通行動変容効果の実証的研究, 土木計画学研究・講演集, Vol.29, 2004.

8) 大塚博保, 鶴谷和子, 藤田悟郎, 市川和子 : 安全運 転態度検查 SAS592 の開発, 科学警察研究所報告交通 編, Vol.33, No.2, 1992.

(2014. 2. 28 受付)

\section{AN ANALYSIS OF RULES OF BICYCLE AND ATTITUDE OF RIDING DURING CITY BICYCLE USERS AND SPORT BICYCLE USERS}

\section{Yuto NAKASHIMA, Hideo YAMANAKA and Junko SANADA}

Sports Bicycles have an advantage for promote long distance commuting and activity for health because higher speed, longer drives can be achieved, comparing with city bicycles which are used widely in Japan. Moreover, sport bicycle users is said to have possibility as the manner leaders on safety cycling. For this reason, it would be important to spread and promote sport type bicycles for the purpose of creation of environmental and healthful cities.

This study aims at making clear the possibility of sports bicycle users as a manner leaders. The author compared the degree of recognition of rules and manners for bicycle, and attitude of riding during city bicycle users and sport bicycle users. As a result, high level sport bicycle users are found to be manner leaders than the other bicycle users. 